Elisete Soares Traesel ${ }^{1}$

Álvaro Roberto Crespo Merlo²

\section{Trabalho imaterial no contexto da enfermagem hospitalar: vivências coletivas dos trabalhadores na perspectiva da Psicodinâmica do Trabalho}

\author{
Immaterial labor in hospital nursing: collective experiences of \\ nurses under the Psychodynamics of Work perspective
}

\author{
${ }^{1}$ Docente do Curso de Psicologia do \\ Centro Universitário Franciscano (Unifra) \\ 2 Docente do Programa de Pós-Gradua- \\ ção em Psicologia Social e Institucional \\ da Universidade Federal do Rio Grande \\ do Sul (UFRGS) \\ Contato: \\ Elisete Soares Traesel \\ Rua Tenente Fraga, n. 138 \\ Bairro Presidente João Goulart \\ CEP 97090-650 \\ E-mail: \\ elisetetraesel@unifra.br
}

Recebido: 25/01/2010

Revisado: 25/04/2011

Aprovado: 03/05/2011

\section{Resumo}

Este artigo apresenta resultados de uma pesquisa fundamentada na Psicodinâmica do Trabalho, realizada em um hospital do Rio Grande do Sul entre 2006 e 2007. Investigou-se a psicodinâmica no contexto de trabalho imaterial da enfermagem, efetuando uma análise das vivências coletivas dos trabalhadores diante das demandas contemporâneas. A partir do estudo, foi possível constatar os efeitos da maximização do trabalho imaterial na contemporaneidade, identificando traços do sofrimento vivenciado pelos trabalhadores e as dificuldades relacionadas às exigências da profissão de enfermeiro na atualidade. Isso leva os profissionais ao individualismo e limita a expressão do reconhecimento e a visibilidade de suas contribuições no trabalho, restringindo as possibilidades de transformação do sofrimento vivenciado no meio profissional em prazer e realização. Além disso, verificou-se que há doação intensa ao trabalho, busca pela perfeição, restrição de tempo e espaço para interação e cuidado, limitação nos espaços de discussão, de convivência, de elaboração compartilhada de sentimentos e falta de relacionamento efetivo da equipe com predominância da técnica e das prescrições. Com os resultados obtidos, entende-se que se faz fundamental a potencialização dos espaços de discussão e de convivência rumo à construção coletiva de emancipação profissional e de novos sentidos para o trabalho na enfermagem.

Palavras-chave: enfermagem; psicodinâmica do trabalho; trabalho imaterial; trabalho e contemporaneidade.

\begin{abstract}
This article is the result of a research based on the Psychodynamics of Work methodology, conducted in a hospital in Rio Grande do Sul, Brazil, between 2006 and 2007. The research purpose was to investigate the psychodynamics of nursing immaterial labor by analyzing socialization among hospital nurses confronted with their contemporary professional demands. The research evidenced the effects of immaterial labor maximization in the contemporary world, as well as nurses' suffering and difficulties when facing their present job demands. These factors lead these professionals into individualism, limit self-recognition and visibility of their professional contribution, reducing the possibility of transforming their suffering at work into pleasure and fulfillment. Among these hospital nurses were also observed: their dedication to the job and search for perfection, time and space restrictions which prevent them from interacting and caring of patients; reduced opportunities to gather, discuss problems, and share their feelings; lack of effective group relationship, overvaluing techniques and prescribed tasks. As conclusion, it is essential to increase nurses' opportunities for discussion and socialization aiming at a collective construction of their work emancipation and of new meanings for their profession.
\end{abstract}

Keywords: nursing; psychodynamics of work; work and contemporaneity; immaterial labor. 


\section{Introdução}

Neste trabalho serão apresentados os resultados de uma investigação baseada nos estudos e nos pressupostos metodológicos da Psicodinâmica do Trabalho, fundamentada por Dejours (1992, 1999, 2004c), que consiste em uma abordagem clínica da atuação profissional, tendo em vista as possibilidades de retomada do sentido do trabalho a partir dos espaços de discussão e da escuta coletiva dos trabalhadores.

Escolheu-se o contexto da enfermagem para o desenvolvimento da presente pesquisa em função desta profissão apresentar peculiaridades que incluem atenção ao paciente, responsabilidades administrativas, bem como exigência profissional constante, em um contexto no qual sua contribuição é, geralmente, imensurável por lidar, concomitantemente, com serviços técnicos específicos da área, cuidados, interação humana e trabalho afetivo. Além disso, produz um bem intangível que se consome ao mesmo tempo em que é produzido - características do trabalho imaterial. Neste sentido, Molinier (2008) afirma que a discrição é essencial para o saber-fazer na enfermagem e é sua permanência como uma figura discreta que caracteriza, na expectativa do outro, a sua competência, o que traz sérias limitações ao seu reconhecimento.

Segundo Dejours (2004a), a inteligência no trabalho está continuamente condenada à discrição, à clandestinidade e é por isso que parte importante do trabalho efetivo permanece na sombra, principalmente nos trabalhos em que os modos operatórios e os procedimentos são rigorosos.

Conforme o autor, esta dificuldade se agrava quando as atividades do trabalho:

evoluem na direção das tarefas imateriais, isto é, quando não há mais produção de objetos materiais [...], em particular no caso das atividades ditas de serviço, onde a parte mais importante do trabalho efetivo é invisível. (DEJOURS, 2004a, p. 30)

Com relação à Psicodinâmica do Trabalho, ela considera a normalidade como um compromisso entre o sofrimento e as estratégias de defesa (DEJOURS, 1999). Enfoca, ainda, o reconhecimento, em seus diferentes modos de expressão, como mediador da construção da identidade no campo social. Este reconhecimento produz sentido ao sofrimento no trabalho e, portanto, promove a realização, a emancipação e, consequentemente, a saúde (DEJOURS, 1992, 1999, 2004b).

Ao definir o escopo da pesquisa, optou-se por conhecer as vivências coletivas dos trabalhadores no contexto do trabalho imaterial maximizado pelo capitalismo em seu modelo atual por considerar que esta é uma importante dimensão do mundo do trabalho na atualidade, como propõem Hardt e Negri (2001) e Lazzarato e Negri (2001).

No que se refere ao trabalho imaterial do enfermeiro nos hospitais, este se encerra no momento de sua produção, sendo que a ele é agregado o próprio trabalhador com suas características pessoais. Esse trabalho é essencialmente afetivo, pois inclui contato e interação na promoção de cuidados que se transformam em bens imateriais.

Segundo Pitta (1994), embora o hospital seja um local preferencial para o avanço científico e tecnológico, quem vai determinar a qualidade e a eficácia da atenção e do tratamento é o trabalho humano. Isto constitui um conflito importante na profissão, pois o investimento fica concentrado na tecnologia e na técnica, desconsiderando os aspectos humanos e a contribuição do trabalhador que, embora continue sendo imprescindível, sente-se descartável neste processo.

Assim, no trabalho de enfermagem, inserido no modelo atual do capital cujo foco está na polivalência, na flexibilidade, nos resultados e na exigência de altos níveis de performance, há uma forte tendência a não valorizar a contribuição deste trabalhador, com fortes impactos sobre a sua saúde.

Segundo Dejours e Bègue (2010), os agravos à saúde mental que podem, inclusive, culminar com o suicídio, conforme constatado em recentes pesquisas, geralmente estão associados a uma desqualificação da contribuição do indivíduo e do não reconhecimento de seu mérito pessoal. Dessa forma, na profissão de enfermagem há um intenso investimento que passa despercebido em um cenário em que o que importa são os resultados, o desempenho e o alcance e superação de metas. Nesta direção, Molinier (2008) afirma que existem atividades, nas quais podemos situar a enfermagem, que são ainda mais invisíveis do que outras. Tais profissões não se concretizam em objetos ou ações técnicas, nem em objetivos diretos, o que dificulta a percepção de sua importância.

Assim, considerando o protagonismo do reconhecimento na construção da identidade e na produção de sentido ao sofrimento no trabalho, este contexto laboral pode ser nocivo à saúde destes trabalhadores, pois o fazer do enfermeiro tende à invisibilidade, tendo em vista que, na atualidade, há uma intensa valorização da tecnologia aplicada à saúde e da precisão da técnica aliada à racionalização dos custos e do tempo de execução dos procedimentos em detrimento do fator humano.

A fim de contextualizar esta pesquisa, articulando as perspectivas clínica e crítica (PÉRILLEUX, 2010), considerou-se importante refletir sobre a natureza do trabalho imaterial do enfermeiro na contemporaneidade, maximizado pela lógica capitalista, conforme acima exposto. Esta preocupação justifica a importância desta pesquisa e o estudo da Psicodinâmica do Trabalho da enfermagem no ambiente hospitalar, buscando, através da Clínica do Trabalho, conhecer as vivências dos trabalhadores deste campo, bem como abrir um espaço de comunicação entre os enfermeiros e de visibilidade de suas contribuições à organização hospitalar. 
Ressalta-se que os resultados do trabalho na enfermagem não são concretos e palpáveis, mas sim baseados em relações, comunicações, rede de informações e doação ilimitada de afeto, características do trabalho imaterial (HARDT; NEGRI, 2001).

Salienta-se, ainda, que o contexto hospitalar parece gerar formas peculiares de sofrimento e/ou prazer e realização no trabalho cujo estudo contribui para as reflexões acerca das estratégias de mobilização e para a potencialização da saúde mental do profissional de enfermagem na atualidade. Sendo assim, um aspecto desta profissão que merece destaque, em função de sua complexidade, é a intensa doação, também capturada pela essência do que é denominado de trabalho imaterial na pós-modernidade. Lazzaratto e Negri (2001, p. 25) salientam que, como prescreve a nova forma de gestão, hoje, "é a alma do operário que deve descer na oficina”. É a sua personalidade, a sua subjetividade que deve ser organizada e comandada. Portanto, a qualidade e a quantidade do trabalho são reorganizadas em torno de sua imaterialidade.

Neste sentido, se uma das especificidades deste fazer está relacionada ao fato do trabalhador formar intensos vínculos com as tarefas imateriais e dedicar-se significativamente a elas, este modo de funcionamento será ainda mais intensificado pela lógica contemporânea de entrega de corpo e alma para a organização.

De acordo com Kirchhof (apud LEOPARDI et al., 1999), está presente no hospital um modelo ideológico de produtividade em que se deve contribuir ativamente para a cura dos corpos para que estes retornem o mais rápido possível ao circuito de produção e consumo. Diante dessa imposição, não há espaço para os enfermeiros adoecerem, sofrerem e lidarem com suas dores, perdas e lutos, pois seu dever é realizar um trabalho discreto, sem emoções que possam alterar a cadência e o ritmo da produção em nossa sociedade.

Pitta (1994) salienta, ainda, que o hospital reproduz o modo de produção capitalista atual, o qual tem transformado suas características de "ofício" em "processo tecnológico de trabalho" com o uso cada vez mais acentuado da informatização, de modernos recursos e técnicas, principalmente nos diagnósticos, bem como nos métodos de trabalho que exigem menos trabalhadores. Isso leva, inevitavelmente, à redução dos postos de trabalho, à dupla ou tripla jornada, ao trabalho temporário e à precarização das relações de trabalho, culminando com profunda insegurança destes profissionais. Aliado a isso, há uma busca por competitividade associado a metas intransponíveis e a um aumento significativo da demanda, com diminuição do tempo para estabelecer interações efetivas com os pacientes.

Outro fenômeno de extrema relevância, com profundos efeitos sobre a atividade da enfermagem, é a globalização. Segundo Silva (2008), as consequências da globalização da economia na contemporaneidade tornam ainda mais complexo o trabalho do enfermei- ro, pois a expansão do comércio transnacional é uma causa direta da proliferação de doenças, dos danos ao ambiente físico e das perdas da qualidade ambiental, afetando a saúde e levando a outros problemas relacionados à desintegração social e à violência. Tudo isso coloca novas exigências ao profissional da enfermagem, que, embora trabalhe em uma empresa que lhe exige produção, vai sentir-se convocado a tomar posições éticas e políticas que não visem apenas à cura, mas que se dirijam à educação, à promoção e à prevenção em saúde. Contudo, o enfermeiro corre o risco de cair na armadilha da rotinização, das normas e prescrições com vistas à qualidade de seus processos e produtos, conforme previsto na agenda das organizações hospitalares contemporâneas, reduzindo, cada vez mais, o espaço para construir vínculos, relações e criar novas formas de cuidado e visando atender as reais necessidades humanas que se apresentam em seu cotidiano.

Segundo Beck (2001), a instituição hospitalar está profundamente inserida na lógica contemporânea de desumanização, maquinização, pressão desenfreada, números e cifras ao invés de seres humanos, aceleração constante, relacionamentos supérfluos e fugazes. Por outro lado, a autora aponta que há saídas para este círculo vicioso desde que seja dada atenção à saúde do trabalhador da enfermagem, porém este espaço para o cuidado ao cuidador ainda precisa ser construído e consolidado no hospital.

Para o trabalhador do contexto pesquisado, uma das principais consequências é a sensação de aprisionamento e desperdício de seu tempo. A exploração é sutil, quase imperceptível, mas seus efeitos são avassaladores. Ao encontro disso, Lazzaratto e Negri (2001, p. 88) afirmam que "o capitalismo contemporâneo não organiza mais o tempo de trabalho, mas o tempo de vida”. Outra consequência importante do trabalho imaterial na enfermagem é a exigência de um nível de desempenho de um "super-homem/mulher", adaptado às novas tecnologias e aos novos modos de gestão próprios do modelo global do novo capitalismo. Entretanto, todo esse desempenho não é visto como uma contribuição a ser reconhecida, mas como uma exigência básica à manutenção no mercado de trabalho.

Assim, constata-se que as organizações estão a todo o momento transformando-se e exigindo mudança por parte deste trabalhador que está perdendo a noção do que representa uma contribuição significativa, e não excessiva, à organização, pois há cada vez mais controles e exigências e, em contrapartida, cada vez menos tempo e espaço para a assimilação das perdas e frustrações, o compartilhar de vivências, a interação efetiva e afetiva com os pacientes e para a construção de relações de trabalho que primem pela cooperação, pela convivência e pela solidariedade. Sendo assim, os trabalhadores da enfermagem estão cada vez mais necessitando de espaços de reflexão, transformação e emancipação (BECK, 2001; TRAESEL; MERLO, 2010). 


\section{Percurso metodológico}

\section{A metodologia em Psicodinâmica do Trabalho}

Dentro dessa perspectiva metodológica, a vivência subjetiva do trabalhador é o ponto de maior relevância, sendo o discurso coletivo o principal material para se tomar contato com a subjetividade dos profissionais.

Logo, o material de pesquisa em Psicodinâmica do Trabalho é, conforme Dejours (2004c), o resultado de uma operação realizada no que foi anteriormente discutido pelo grupo. Esta operação refere-se ao que foi dito e que pode ser reconhecido como discurso, ao que é uma formulação repleta de originalidade, vida, engajamento e subjetividade. Dessa forma, o material de interpretação em Psicodinâmica do Trabalho é uma observação comentada em que, de acordo com o autor, o trabalho de objetivação tem seu foco deslocado da objetivação da fala dos trabalhadores para a objetivação da intersubjetividade.

Quanto ao método de interpretação, o pesquisador deverá ficar em uma posição de interlocutor e não de especialista, pois o autor acredita que é esta posição que torna possível a abertura para o discurso relativo ao sofrimento e ao prazer. Discurso este passível de escuta e de interpretação, que abre espaço para o sujeito e lhe possibilita sair de uma posição de submissão rumo à emancipação. $\mathrm{O}$ mesmo autor adverte que o discurso deve ser entendido nesta escuta não como uma série de palavras, mas como uma atitude que implica um ato de pensar, diferente da atividade de pensar.

Neste sentido, a observação clínica é essencial e a redação desta observação é realizada a partir da própria pesquisa, em um segundo momento. Ou seja, logo após o trabalho de campo, a partir das informações que ficaram retidas na memória do pesquisador, a redação será desenvolvida. Entretanto, para encontrar:

a formulação precisa de um trabalhador do grupo ou de um pesquisador, é possível recorrer às anotações realizadas durante a sessão e, excepcionalmente, a fitas gravadas durante a sessão. (DEJOURS, 2004c, p. 119)

Isto é, a redação da observação deve, necessariamente, ser fundamentada nos discursos dos participantes da sessão.

Nesta pesquisa, foi utilizado o recurso da gravação para garantir a fidedignidade e a precisão dos relatos das trabalhadoras, conforme propõe Dejours (2004c) para o desenvolvimento desta técnica. Entretanto, a interpretação e a análise clínica do trabalho foram desenvolvidas a partir da intersubjetividade e da intercompreensão, possibilitadas pelo espaço de discussão e pela observação clínica.

O princípio fundamental de investigação situou-se, então, na consideração de que as noções sobre as vivências subjetivas qualitativas dos trabalhadores somente podem ser elaboradas através das relações intersubjetivas, isto é, no espaço coletivo, sendo que é na narrativa do pesquisador que se encontra a maior riqueza para a discussão. Nesta direção, Molinier (2003) salienta que a Psicodinâmica do Trabalho está alicerçada sobre uma metodologia que privilegia a intersubjetividade. Em outras palavras, é a própria subjetividade do pesquisador que é mobilizada no intuito de acessar a subjetividade do outro.

Na visão de Dejours, o foco da Clínica do Trabalho é abrir espaço à possibilidade dos agentes refletirem sobre a sua situação em relação ao trabalho e sobre as consequências dessa relação, mergulhando na dialética ator-sujeito. Busca-se, assim, estudar:

o lugar dos sujeitos em sua relação com o trabalho [...] o espaço deixado ao indivíduo para se servir do trabalho como 'ressonância metafórica' à cena da angústia e do desejo. (DEJOURS, 2004c, p. 126)

E, ainda, analisar os possíveis obstáculos que o trabalho coloca à possibilidade de ressonância metafórica e que podem ser vistos como um fator determinante do poder estruturador ou desestruturador do trabalho em relação à economia psíquica dos trabalhadores. Para Sznelwar (2008), a metodologia em Psicodinâmica do Trabalho fundamenta-se na palavra do sujeito em situação de grupo, tornando possível a expressão de sua vivência e a elaboração, de forma compartilhada, da reflexão referente à relação entre sofrimento e prazer no trabalho. Portanto, nesta prática, é importante um engajamento efetivo dos pesquisadores que estão na condução do processo. Merlo e Mendes (2009) salientam que uma característica relevante desta metodologia é visar ao coletivo de trabalho, não se voltando aos indivíduos isoladamente.

Desse modo, as intervenções dos pesquisadores não têm fins terapêuticos individuais, mas sim de análise da organização de trabalho. Nesta direção, tais investigações situam-se entre a patologia e a normalidade, partindo do pressuposto de que a saúde mental é resultante também das formas como os sujeitos-trabalhadores reagem e agem diante do sofrimento relativo aos constrangimentos que se impõem na organização de trabalho. Esses constrangimentos englobam o constante encontro com a imperfeição e a falta como indissociáveis de seu fazer, constituindo "a condição permanente do trabalho que será sempre inacabado" (MERLO; MENDES, 2009, p. 143).

Então, o foco da Psicodinâmica do Trabalho é buscar a compreensão dos fatores psíquicos e subjetivos que são mobilizados nas relações de trabalho. Nesse sentido, são estudadas dimensões menos visíveis vivenciadas pelos trabalhadores na organização de trabalho, dentre elas, mecanismos de "cooperação, sofrimento, mobilização da inteligência, vontade e motivação e estratégias defensivas” (LANCMAN; HELOANI, 2004, p. 82).

Para alcançar esse propósito, usa-se um método específico que entrelaça a intervenção à pesquisa, pautada pelos princípios da pesquisa-ação, mas que, devido às suas especificidades, intitula-se "Clínica do Trabalho", considerando que tem o intuito de intervir nas situações concretas de trabalho, buscando a compreen- 
são dos processos psíquicos envolvidos e construindo avanços teóricos e metodológicos generalizáveis a outros contextos.

Mendes e Morrone (2010, p. 40) acrescentam que a metodologia em Psicodinâmica do Trabalho permite que:

por meio da linguagem, o sujeito expresse as ambivalências entre o seu mundo interno e a práxis do trabalho vivo - o acesso à vivência do trabalho só existe se mediatizada pela palavra.

Assim, na Clínica do Trabalho, pelo relato das vivências dos trabalhadores, pode-se escutar o invisível do sintoma, possibilitando ao sujeito aprender com o sofrimento.

Por assim dizer, as autoras entendem que, através dessa escuta, "novas formas de vida surgem, permitindo a transformação do sofrimento em mobilizações para a busca do prazer na atividade profissional” (MENDES; MORRONE, 2010, p. 41). Salientam, ainda, que o princípio metodológico da Clínica do Trabalho é a interpretação da fala para a ação, objetivando a perlaboração de modos defensivos. Ou seja, enfocam-se, principalmente, as ações usadas pelos trabalhadores a fim de realizar o confronto com a organização do trabalho, sendo este responsável pela maneira pela qual as estratégias são construídas e desenvolvidas. Sendo assim, essas ações podem ser abertas e favoráveis aos espaços de expressão do sofrimento, reconhecimento e cooperação, promovendo saúde ou, em contrapartida, podem constituir ambientes propícios ao adoecimento. Em síntese, estão interligados na análise clínica do trabalho três aspectos fundamentais: o sofrimento, as vivências no trabalho e o reconhecimento.

Quanto à análise dos resultados em Psicodinâmica do Trabalho, bem como apontam Lancman e Heloani (2004, p. 84), pode-se destacar que:

a delimitação dos objetivos específicos, o detalhamento das estratégias metodológicas, o trabalho de campo, análise do material, a avaliação, a validação e coleta de dados e sua análise ocorrem, simultaneamente, ao longo da intervenção.

Ainda, no que se refere à validação, esta é feita em dois momentos: durante a própria pesquisa e no momento de sua devolução aos trabalhadores. Nesta direção, Merlo e Mendes (2009, p. 152) constatam que essa metodologia "revela-se um instrumento para intervenção, prevenção e transformação de processos de trabalho agressivos à saúde psíquica”. Ou seja, para os autores, a Psicodinâmica do Trabalho vem ao encontro da saúde do trabalhador, propiciando a melhoria dos processos de trabalho prejudiciais à saúde mental dos envolvidos. Em concordância, Sznelwar (2008) defende que a criação de espaços de discussão, tal como proposto pela metodologia em Psicodinâmica do Trabalho, pode, ainda, promover uma forma de engajamento no trabalho que atue como mediadora na renovação do desejo. Ou seja, segundo o autor, os espaços de discussão podem possibilitar o acesso ao prazer advindo do reconhecimento do fazer e das contribuições à organização de trabalho, o que mediatiza a construção da identidade no registro social.

Considera-se importante salientar, ainda, a dimensão ético-política dessa metodologia. Aplicar a Psicodinâmica do Trabalho "implica o engajamento subjetivo, político e ético do pesquisador" (MERLO; MENDES, 2009, p. 147). A mobilização do fazer em busca de transformação deflagra uma mobilização que é também sociopolítica. Neste sentido, caminha-se na Psicodinâmica do Trabalho em direção à emancipação do sujeito, pois pensar e falar mobilizam o sujeito para a ação sobre o trabalho.

Pode-se compreender, assim, que "a psicodinâmica do trabalho, pode contribuir ativa e eticamente, na construção de espaços de comunicação abertos à transformação" (TRAESEL; MERLO, 2009, p. 108). Estes espaços são extremamente importantes como geradores de saúde e realização para o trabalhador e para a organização de trabalho na superação de seus limites.

\section{Procedimentos}

A presente pesquisa foi desenvolvida em um hospital privado, situado em uma cidade de porte médio no interior do estado do Rio Grande do Sul, conveniado ao Sistema Único de Saúde (SUS), que atende a uma demanda regional de pacientes deste sistema. Este local de pesquisa foi definido por conveniência, considerando que estava sendo estudada a natureza deste trabalho, bem como o sofrimento e as possibilidades de realização na enfermagem dentro do contexto hospitalar.

Inicialmente, a pesquisadora estabeleceu contato com a coordenação de enfermagem, que, com o apoio da direção do hospital, apresentou receptividade à proposta de pesquisa expressando uma demanda à mesma.

Após aprovação da pesquisa pela instituição, realizaram-se as seguintes etapas: pesquisa inicial para levantamento de informações que incluíram alguns contatos iniciais e entrevistas informais com os enfermeiros; visita ao hospital em funcionamento e conhecimento de sua dinâmica e organização de trabalho; e, por fim, escuta de um grupo de trabalhadoras da enfermagem que participaram dos encontros por livre adesão. A pesquisadora propôs a discussão de temas relativos às vivências subjetivas na situação de trabalho, tendo como norteadores os objetivos da pesquisa que foi iniciada em 2006 e concluída em 2007, quando foi efetuada a devolução e discussão dos resultados com as participantes.

Salienta-se que a pesquisa inicial e as entrevistas informais não serão apresentadas na discussão dos resultados, pois tiveram como objetivo apenas conhecer a organização e o perfil do grupo antes de iniciarem os encontros.

Foram realizados quatro encontros com enfermeiras do hospital, sendo que o grupo não incluiu técnicos de enfermagem. Todas as enfermeiras participantes tinham atividades de gestão e de cuidado, com maior ênfase ao 
papel de gerenciamento das equipes. O grupo teve de 8 a 10 participantes por reunião, todos eram do sexo feminino, com idades entre 24 e 42 anos, representantes de todas as unidades do hospital. A discussão efetuada com o grupo foi gravada para possibilitar o acesso às formulações precisas dos participantes e garantir a fidedignidade dos dados. Após a transcrição das falas, as gravações foram destruídas. Cada encontro teve duração de 2 horas, aproximadamente, e uma periodicidade quinzenal.

Ao todo participaram da pesquisa 11 enfermeiras. Salienta-se que as participantes não foram sempre as mesmas devido a eventualidades que impediram a participação de algumas em todos os encontros. Isso não prejudicou a pesquisa, considerando que, para Dejours (1992), não há problema se os participantes se alternarem, pois o que está sendo estudado não é a história individual, mas sim a organização de trabalho e as relações entre sofrimento e possibilidades de reconhecimento e saúde no trabalho. A escuta do grupo esteve centrada nos comentários relacionados ao seu contexto de trabalho, seus conflitos e contradições, tomando a palavra como um ato no qual está representada a subjetividade do trabalhador, sua situação em relação ao trabalho e os impactos destas vivências nas demais áreas de sua vida, focando, principalmente, em suas vivências relativas ao ser enfermeiro, ao sofrimento no trabalho, ao reconhecimento de seu trabalho e às possibilidades de realização. Também foram abordadas as repercussões destas vivências em sua saúde. Refletiu-se, ainda, junto ao grupo pesquisado, a respeito da abertura ou não da organização para espaços de discussão e de visibilidade à contribuição do enfermeiro.

Fundamentada na metodologia acima descrita, os resultados são apresentados na forma de um relatório comentado que aborda a interpretação do pesquisador e a reflexão efetuada pelo grupo no decorrer da pesquisa, ilustrada pelas formulações das trabalhadoras. Suas falas serão apresentadas a seguir, através de citações diretas. A validação da pesquisa e sua interpretação aconteceram durante a própria pesquisa, junto ao grupo. Salienta-se que, a fim de preservar as identidades das participantes, foram utilizados nomes fictícios nos relatos, que são total e completamente diferentes dos verdadeiros.

Ressalta-se ainda que no primeiro encontro com o grupo foram explicitados os objetivos do trabalho, bem como os princípios norteadores da pesquisa, sendo reforçado o sigilo absoluto em relação às questões que seriam debatidas. Além disso, todas as participantes assinaram o Termo de Consentimento Livre e Esclarecido, que consiste em declarar a ciência de sua participação na pesquisa e livre utilização das informações obtidas por parte dos pesquisadores.

\section{Resultados e discussão}

Os resultados a seguir refletem os conceitos centrais em Psicodinâmica do Trabalho: estratégias defensivas, psicodinâmica do reconhecimento e espaço de discussão.
Doação intensa ao trabalho - estratégia defensiva e sofrimento no contexto do trabalho imaterial da enfermagem

A partir da escuta coletiva, as enfermeiras participantes da pesquisa relataram seus sentimentos em relação ao trabalho, apontando a natureza deste e refletindo sobre suas vivências no exercício da profissão. Assim, a Clínica do Trabalho possibilitou o acesso ao invisível dessa atuação profissional a partir da palavra e da intersubjetividade.

Relacionando estas vivências às características inerentes ao trabalho imaterial na contemporaneidade, constatou-se que a enfermeira lida com afetos e interação humana conforme propõe Hardt e Negri (2001). Neste contexto, não há limites claros para o início e o fim das atividades, o que faz com que a atuação profissional extrapole o próprio papel profissional, levando, por vezes, à exaustão, conforme apontam as enfermeiras do grupo. Segundo elas, embora haja horários definidos para os turnos, há uma demanda implícita que lhes exige ir além de seus turnos, se for necessário, em benefício do paciente ou que, dentro de seu turno, atendam a todas as demandas que se apresentem. Porém, o imprevisível e o inusitado se impõem, impossibilitando a conclusão das tarefas pelas quais se sentem responsáveis mesmo fora do hospital. Além disso, apontam que não conseguem desligar-se de seu trabalho, pois, quando saem do hospital, continuam a preocupar-se com o que poderá acontecer com os pacientes e com sua equipe de trabalho em sua ausência.

Esta exaustão está atrelada à exigência de perfeição e pode-se considerar, através da observação clínica do grupo, que consiste em uma estratégia defensiva coletiva (DEJOURS, 2004b; GERNET, 2010). Conforme Gernet (2010), os trabalhadores constroem e mantêm coletivamente estratégias que visam à proteção contra os sofrimentos relativos aos constrangimentos de seu trabalho. Estas estratégias têm o intuito principal de possibilitar que continuem a trabalhar e suportem as contradições da organização. Dejours (2004b, p. 51) aponta que tais estratégias garantem que o trabalhador mantenha-se em um estado de normalidade que se dá como resultado de um "equilíbrio instável, fundamentalmente precário, entre o sofrimento e as defesas contra o sofrimento". O autor adverte, porém, que, embora estas defesas sejam importantes na preservação da normalidade, elas pressupõem um equilíbrio, sob pena de impedir que o sofrimento no trabalho possa encontrar sentido.

Quando as enfermeiras afirmam que precisam exigir de si próprias o máximo e a perfeição, considerando que precisam saber dominar o conhecimento e responder a tudo, trazem à luz esta defesa: "A gente é um pouquinho de cada profissional (...); acaba indo além. É uma das profissões mais desgastantes que existe" (Nina). Outra participante complementa: "Temos que ser sempre perfeitas [...]; temos que dar conta de tudo, afinal, somos enfermeiras" (Susi). 
A análise crítica deste cenário permite o entendimento de que as enfermeiras se mantêm conectadas ao seu trabalho buscando, continuamente, um alto nível de desempenho para preservar um estado de adaptação às exigências de seu fazer. Entretanto, esta estratégia defensiva diante das contradições de seu trabalho acaba por constituir uma submissão às exigências contemporâneas de pressa, polivalência e elevada performance. Com isso, retoma-se a afirmação de Nardi (2003, p. 44) de que a partir "das reviravoltas do capitalismo emergiram dispositivos assujeitadores mais sutis e mais eficazes". Nesta direção, Beck (2001) assevera que os trabalhadores da enfermagem têm uma intensa preocupação em cumprir as prescrições, o que os leva a desconsiderar suas necessidades individuais, ou seja, se é esperado que trabalhem sem cansaço, será feito tudo para que essa expectativa seja atendida, colocando a excelência do desempenho em primeiro lugar, acima dos limites de seu próprio corpo. Acrescenta-se a isso os problemas de tempo, a imprevisibilidade, a evolução de cada paciente, bem como a divisão técnica do trabalho da equipe de enfermagem, fatores que moldam um ambiente propício à pressão e à sobrecarga e que exige um senso de urgência, vigilância e disposição constante.

A fim de suportar esse cotidiano de trabalho, o profissional tende a anestesiar o próprio corpo, conforme verificado na pesquisa, sendo que esta atitude persiste mesmo após a jornada de trabalho, da qual tem muita dificuldade de desligar-se. Relatam, ainda, que se mantêm, por um longo tempo após o seu turno, em estado de alerta, sem conseguir desconectar-se de sua rotina laboral exaustiva: "Em casa é como se eu ainda estivesse no trabalho, não desligo [...] a exigência é a mesma[...] acabo esquecendo de mim" (Paola).

Nesta direção, constatou-se que este profissional tem um nível de responsabilidade que transcende as horas normais de trabalho e o faz assumir também as funções de outros profissionais, o que o induz a levar não necessariamente seu trabalho, mas suas preocupações, perdas e conflitos para sua casa, ou seja, o trabalho segue em seu íntimo para além do seu ambiente de trabalho.

Outro aspecto evidenciado é o desejo de dar conta de tudo, buscando ser polivalente e eficaz. A participante Beth ilustra essa afirmação: "Os outros funcionários não assumem dessa forma assim sem limites”. Susi acrescenta: "O enfermeiro se responsabiliza também pela postura dos demais profissionais [...]”.

Assim, infere-se que a questão afetiva que permeia o trabalho na enfermagem é repleta de contradições, pois a doação ilimitada do enfermeiro em prol do paciente pode trazer efeitos nocivos para sua própria saúde (TRAESEL; MERLO, 2010). Nesta direção, uma das contradições reside exatamente na dificuldade enfrentada por este profissional em conciliar, de um lado, a gestão, a burocracia, o número de procedimentos multiplicado pelo número de pacientes e, de outro, o contato mais demorado e a escuta das necessidades do paciente e de sua família. Isto os leva a um intenso conflito que se situa entre o cumprimento das normas e a realização das tarefas e a difícil concretização da humanização do cuidado que exige tempo e investimento. Outra contradição está atrelada à tendência contemporânea das organizações hospitalares de colocarem, para os enfermeiros, obrigações administrativas, tarefas burocráticas e de gestão, sendo que estas levam, gradativamente, ao afastamento do paciente e à pressa na execução dos procedimentos a fim de cumpri-las dentro dos prazos exigidos.

Outrora, o enfermeiro já acumulava funções, entretanto, na contemporaneidade, agrega-se ao seu trabalho a pressão de metas cada vez mais acirradas em busca de competitividade, produtividade e excelência de resultados em um contexto no qual efetuar um bom procedimento não é o bastante. É preciso ir além, superar continuamente as expectativas. Aliam-se a isso os inúmeros controles e exigências instigados pelo primado da tecnologia aplicada à saúde, do rigor da técnica aliado à racionalização dos custos e do tempo de execução dos procedimentos, culminando com um desinvestimento nos aspectos humanos e afetivos que deveriam nutrir o exercício da profissão. Esta sobrecarga das demandas gerenciais contemporâneas tende à derrocada do prazer no trabalho da enfermagem atrelada à perda do sentido do sofrimento vivenciado neste cotidiano laboral.

Desta constatação, advém mais uma importante contradição, isto é, o reconhecimento do trabalho, segundo as participantes, advém dos pacientes. Assim, ao não poder dedicar-se a eles na intensidade que gostariam, sentem-se frustradas por não ter essa retribuição de sefazer, conforme será abordado no próximo tópico.

Pode-se citar ainda, brevemente, outras contradições constatadas no decorrer da pesquisa: exigência de extremo preparo técnico e pouco incentivo para o preparo emocional, ou seja, pouca atenção às necessidades afetivas e subjetivas deste profissional; realização de atividades de gestão, porém com pouca autonomia no gerenciamento aliada a sentimento de impotência para concretizar mudanças efetivas, bem como sentimento de injustiça na remuneração pelo cargo de gestor; precariedade de recursos e materiais diante de toda evolução tecnológica; políticas de humanização do atendimento em um cenário que prima por produção e desempenho; e, por fim, exigências crescentes e pouco investimento em qualificação do profissional.

Todas essas contradições, acima apontadas, constituem fontes de sofrimento e conflito no exercício da profissão que somente podem encontrar vias de superação e transformação em soluções criativas, através da escuta coletiva, abrindo espaços de saúde nas organizações hospitalares. Faz-se importante ressaltar que este consiste em um dos principais propósitos da metodologia da Psicodinâmica do Trabalho.

Uma reflexão a partir dos estudos sobre contemporaneidade e trabalho permite o entendimento de que estas contradições são apropriadas e alimentadas pelo atual 
modo de acumulação de capital, que exige o máximo do profissional, obstrui os espaços de criação e neutraliza a potência dos coletivos. São formas de dominação da atualidade cujo palco é o mundo do trabalho.

De acordo com Merlo e Lapis (2005, p. 27), na atualidade, há uma tendência à precariedade nas relações profissionais. No toyotismo, atual modelo de organização social do trabalho, as formas de controle são, na verdade, autocontroles, ou seja:

a introjeção dos valores da empresa, o estímulo ao orgulho profissional, o controle 'corpo a corpo' e a emulação psicológica, a qual visa, antes de tudo, esconder a oposição de interesses [...] num clima de pseudoliberdade de expressão.

Nesta direção, pode-se abordar o amor ao trabalho, característico da enfermagem, o qual, inserido no modo de produção toyotista, transforma-se em um autocontrole levando à intensificação do trabalho e, consequentemente, ao desgaste físico e psicológico, em especial nas profissões voltadas ao cuidado.

Molinier (2008) defende que a devoção ao trabalho estaria na origem do esgotamento e que o ato de cuidar preconiza condições organizacionais concretas. Esta devoção é abordada pelo grupo ao ser mencionado o amor ao trabalho como sendo fator muito importante para o bom exercício da profissão. Entretanto, este "amor" ou este "gostar muito de seu trabalho", capturado pela atual lógica do capital, parece fazer com que este trabalhador extrapole suas horas de trabalho e desrespeite os seus próprios limites em nome do amor pela profissão, conforme relata a enfermeira Beth: "Amo muito meu trabalho, muito mesmo, trabalho muito por amor ao que faço". E ainda: "Não mudaria de profissão [...]; trabalho muito mesmo e nem percebo. Não paro pra pensar [...], vou trabalhando muitas horas porque gosto".

Esta doação abnegada em nome do "amor pelo trabalho" é apontada por Gonzáles (2001) como relativa à história da profissão, que carrega marcas profundas de subalternidade. Este perfil de abnegação constituiria, então, na perspectiva da autora, um entrave para estas profissionais em mostrar o seu valor, lutar pelos seus direitos e mudar sua atitude em relação ao trabalho. Beck (2001) discute o mecanismo de defesa de sublimação, reforçado por esse caráter de renúncia e submissão, afirmando que o problema não está no gostar da profissão ou no uso deste como mecanismo de defesa, mas no fato de que este tem sido, frequentemente, usado no sentido de evitar o enfrentamento dos problemas relativos à profissão. Assim, desprender-se deste perfil e do apego à "profissão-missão" propiciaria um caminho para desalienação rumo à conquista de direitos enquanto profissional. Entretanto, na atualidade, isto se torna cada vez mais difícil, sendo que esta característica da profissão tem assumido contornos cada vez mais acentuados, fazendo proliferar a insegurança aliada à redução dos postos de trabalho e à instabilidade no emprego.
Sennett (2004) aborda esta questão sob outra ótica, fazendo referência aos novos controles e seus efeitos. A visão deste autor permite compreender os motivos desta exigência de doação ilimitada. Ele afirma que, na realidade, a ordem atual impõe novos controles ao invés de apenas eliminar as regras antigas. Além disso, esses novos controles são de difícil compreensão. Nesta mesma direção, Hardt e Negri (2001, p. 78) assentam que o controle é, assim, uma intensificação e uma generalização da disciplina, em que as fronteiras das instituições foram ultrapassadas, tornadas permeáveis, de forma que não há mais distinção entre o fora e o dentro.

Lazzaratto e Negri (2001) colocam que o capitalismo contemporâneo não apenas organiza o tempo de trabalho, mas também acaba tomando espaço no tempo de vida. Esta afirmação é ilustrada pela fala de uma participante do grupo, que, por vezes, precisa alterar a sua rotina familiar em função do trabalho: "Quando chego em casa, é hora de dormir [...], mas, aí, a gente não quer deixar o filho com a babá, que já ficou tantas horas sem a gente" (Vivian).

Relacionada a esta estratégia de trabalhar incessantemente para lidar com o real deste trabalho, verificou-se, ainda, a necessidade de aproveitar ao máximo o tempo e o sentimento de emergência contínua em relação ele mesmo, conforme relato: "Não quero, não posso perder tempo [...]; ir ao banheiro pode ser perda de tempo; parar pra conversar, não dá; lanche é rapidinho. Já me acostumei. Só me preocupo se paro para pensar" (Renata).

Esta vivência relatada evidencia a demanda contemporânea de pressa e superficialidade, sendo que, atualmente, parar para pensar, conversar e cuidar de si é visto como perda de tempo. É o ônus de viver nesta sociedade que Sennett (2004) denomina sociedade impaciente, a qual se concentra no imediato, vivido de forma imperceptível, silenciosa e intensa nesta profissão, levando à perda da noção daquilo que tem valor duradouro, como, por exemplo, a família, a interlocução e o cuidado de si.

Associado a isso, as participantes relataram ansiedade e desejo de atender a tudo e a todos e afirmaram que vivem um constante conflito, pois constatam, cotidianamente, que isto é impossível: "O fato é que a gente quer a perfeição, quer ver a unidade funcionar [...], mas mesmo com tanto trabalho, a gente não consegue agradar a todos" (Zilá). Outra participante complementa: "Não aguento mais, mas é assim mesmo [...]. Não sei se estou feliz, se estou triste, só sei que eu trabalho muito mesmo, até doente [...] a gente esquece da gente mesmo" (Suelen).

A doação enquanto defesa remete a uma intensa angústia e frustração, pois as participantes deram-se conta de que, por mais que deem o melhor de si, ficam com a sensação de que o trabalho poderia ter sido melhor, de que sua doação nunca é o suficiente, de que faltou algo. Sendo assim, muitos profissionais enfermeiros têm incerteza e insegurança quanto aos resultados de seu trabalho e responsabilizam-se pelos 
fracassos, como afirma Sandra, uma das participantes da pesquisa: "Tudo acaba sendo problema meu, me sinto responsável pelo que fazemos e também pelo que deixamos de fazer".

Esta defesa culmina com a anulação de si mesmo e redunda em uma sobrecarga imensa sem significação, pois não há espaço para a reflexão sobre o trabalho ou para a perlaboração do sofrimento, o que leva ao trabalho vazio, ao limite das forças, quando as suas defesas fracassam, e ao adoecimento físico e psíquico. Neste sentido, Martins (2010), considera que, embora as estratégias coletivas consistam em um poderoso instrumento na luta contra o sofrimento vivenciado no trabalho, acabam atuando como uma "armadilha psicológica”, pois nutrem a aceitação das contradições e dos constrangimentos da organização de trabalho, reforçando a submissão e a alienação, o que culmina em grandes prejuízos para a saúde do trabalhador.

A doação infinita da enfermeira acaba, assim, por constituir uma barreira ao enfrentamento das contradições do trabalho, limitando de forma significativa a transformação do sofrimento em prazer, pois reduz os espaços de convivência, comunicação e visibilidade diante da imersão contínua no fazer.

A partir de suas pesquisas em Psicodinâmica do Trabalho, Gernet (2010) adverte que a falta de comunicação e convivência, ou seja, o silêncio no local de trabalho, frequentemente, está relacionado com o fracasso da dinâmica do reconhecimento. Como se pode observar na seguinte passagem: "Quando a inteligência no corpo sofre um impasse, quando ocorre uma deserção do convívio, permanece apenas o sofrimento" (GERNET, 2010, p. 73).

Esta dinâmica no contexto pesquisado será abordada a seguir.

\section{A psicodinâmica do reconhecimento na enfermagem}

Com relação a este tema, Dejours (2004b, p. 62) afirma que "a dinâmica do reconhecimento para com as contribuições da organização do trabalho empenha de fato a problemática da saúde mental”. Ou seja, é através do reconhecimento que o trabalhador pode transformar o sofrimento vivenciado em prazer e realização.

Gernet (2010, p. 73) acrescenta que a identidade é "a armadura da saúde mental”, estando sempre em construção, não podendo ser alcançada solitariamente e necessitando do olhar do outro. Assim, o trabalho torna-se o mediador insubstituível no processo de ampliação e estabilização da identidade que ocorre através do reconhecimento da importância do fazer.

Entretanto, a análise clínica das vivências relatadas pelo grupo de enfermeiras, no decorrer da pesquisa, revela que a dinâmica do reconhecimento encontra-se obstruída diante da exigência contínua de um bom desempenho profissional, pois esta é considerada parte do ofício e da missão da enfermeira, não lhe garantindo o reconhecimento de sua contribuição. Podemos observar essa ideia na fala de Suelen: "Bom desempenho na nossa profissão é obrigação, é básico [...], então, não há reconhecimento". Percebe-se que os espaços de visibilidade, comunicação e cooperação encontram-se bloqueados, limitando as formas de expressão do sofrimento e de sua transformação em prazer e realização.

A análise das formas de reconhecimento revelou que, para as enfermeiras participantes, o principal reconhecimento advém do paciente, sendo a modalidade considerada mais importante. Com relação ao reconhecimento, para a enfermeira Lisa:

É difícil receber de chefia, até vem, mas é mais difícil. Eu sinto reconhecimento do paciente. Quando a gente tá fazendo uma coisa e o paciente agradece. Esse é o maior reconhecimento.

Outra participante acrescenta: "É isso que dá maior satisfação pra gente. A gente nota o grau de carinho que eles têm pela gente, com a forma que a gente trata o paciente” (Brenda). Zilá também contribui com a fala: "O reconhecimento vem mesmo do paciente. O seu sorriso, uma palavra quando a gente dá atenção. O principal reconhecimento é o paciente, o que ele fala do teu trabalho".

Todas as participantes do grupo relataram vivências deste tipo de reconhecimento em seu cotidiano de trabalho. Entretanto, o fato de apontarem que esta é a principal fonte de reconhecimento leva à constatação de que, quando este reconhecimento não ocorre, o seu trabalho perde sua razão de ser. Demonstra, ainda, o quanto as relações afetivas e os resultados intangíveis próprios das tarefas imateriais fundamentam o reconhecimento deste trabalho e, portanto, seu sentido.

Nesta perspectiva de análise, considera-se importante apontar que as falas das participantes evidenciaram uma contradição, conforme já referido. Isto é, elas relataram que o reconhecimento do paciente é o principal e este advém do cuidado e da atenção dispensados a ele, porém, concomitantemente, expõem que é muito difícil manter esta atenção, pois outras responsabilidades as absorvem significativamente, distanciando-as do paciente. A enfermeira Sandra afirma que:

A enfermagem tem muitas obrigações, muita burocracia, muita responsabilidade, mas a gente não pode deixar de lado o paciente, a humanização. Às vezes, é difícil conciliar tudo.

Outra participante complementa:

É muita burocracia, responsabilidade [...], que a gente acaba deixando, com a rotina, esse lado de pensar mais no paciente. Poderia falar 'agora vou puncionar sua veia' e ficar conversando um pouquinho, mas não dá tempo [...] acaba fazendo muita coisa. (Nina)

Além disso, essa participante complementa sua fala, como se vê a seguir, exemplificando o que pode ser feito para estabelecer uma boa relação com o paciente:

Não precisa realizar técnica nenhuma [...], por exemplo, é só visitar os pacientes pra avaliação e conver- 
sar, que o paciente e a família já te agradecem. E tu te sente feliz [...], mas nem sempre dá para fazer isso, daí a gente fica sem esse retorno. (Nina)

A importância concedida a esta fonte de reconhecimento aponta para o conflito entre atender às exigências da contemporaneidade, potencializando o tempo de trabalho e atendendo a muitos superficialmente, ou prestar cuidados sem pressa, dar atenção e dedicar-se aos relacionamentos que alimentam o sentido de seu trabalho. Faz-se importante evidenciar que, de acordo com os comentários do grupo, se aquelas enfermeiras pudessem escolher entre suas responsabilidades, escolheriam o cuidado ao paciente e dispensariam mais tempo para interação e diálogo com ele, pois se prepararam para tal e escolheram essa profissão por conta disso. Entretanto, sentem-se presas a tarefas administrativas, burocráticas e ao excesso de demandas.

Pode-se interpretar também que este prazer no cuidado com o paciente, relatado como fundamental, relaciona-se significativamente ao fato de que é deste cuidado que advém a valorização de seu trabalho, ratificando a tese da Psicodinâmica do Trabalho, no que se refere à centralidade do reconhecimento na transformação do sofrimento vivenciado no meio profissional. Em contrapartida, a dificuldade em realizar este cuidado, em função das inúmeras responsabilidades elencadas pelo grupo, e, portanto, não receber o retorno esperado, pode constituir uma importante fonte de sofrimento e adoecimento nesta profissão.

Quanto ao reconhecimento de utilidade que, segundo Dejours (1999, 2004b), refere-se ao retorno dos superiores sobre a importância do trabalho, foi apontado que ele ocorre muito raramente. O que vivenciam é a cobrança por resultados e severas críticas aos erros, como se o bom desempenho fosse mesmo apenas uma mera obrigação.

O reconhecimento dos pares, denominado por Dejours (1999, 2004b) como reconhecimento de estética ou julgamento da beleza do trabalho, não foi abordado pelo grupo. As participantes apontaram que em seu cotidiano de trabalho não há muito tempo para contato, sendo que cada uma cuida de uma unidade e dedica-se integralmente a esta tarefa. Quando é possível, e em situações muito extremas, desabafam com alguma colega mais próxima sobre suas dificuldades, sendo que a cooperação é voltada à técnica e aos procedimentos.

Sob essa ótica, é importante considerar que, tal como propõe Dejours (2004e), a cooperação não pode ser prescrita, bem como as condições éticas das relações de trabalho não residem na técnica, mas sim na prática. Ao mencionarem que não há tempo para a comunicação entre os pares, as participantes ressaltam que encaram isto com naturalidade, não considerando como um problema, mas sim como mais uma especificidade de sua profissão, deixando transparecer que o individualismo supera o desejo de solidariedade e cooperação, apontando para o que Sant'Anna (2001) deno- mina como indivíduo soberano, proprietário de si, que busca incessantemente atender ao imperativo contemporâneo de dar conta de si mesmo.

Esta tentativa de cumprir a demanda de dar conta de si mesmo é revelada no grupo e pode ser ilustrada pelo seguinte relato: "A gente tem que reconhecer a si mesmo" (Vivian). Todas as enfermeiras concordaram com a participante, desnudando mais uma defesa que as leva ao isolamento e ao vazio do si mesmo. Esta busca pelo reconhecimento de si, presente nas falas, certamente não deixa impune a saúde destas trabalhadoras, pois, segundo Dejours (1999, 2004b) e Gernet (2010), o reconhecimento enquanto construtor da identidade e mediador da saúde e da realização somente pode ser concedido pelo outro que confere valor ao fazer e à contribuição à organização de trabalho.

Esta tentativa de reconhecer a si mesmo remete, ainda, à reflexão sobre a solidão e o individualismo contemporâneo (DEJOURS, 1992, 2004d; NARDI, 2003). Dejours (2004d) associa este cenário às patologias da solidão consequentes da erosão da solidariedade e do rompimento do tecido social no trabalho.

A análise deste contexto permite a constatação de que a rotinização e a robotização associadas aos horários, aos ritmos e aos turnos de trabalho, bem como a fragmentação e a divisão do trabalho da enfermagem, a invisibilidade e a imaterialidade das contribuições e o enfraquecimento dos laços sociais não tornam este ambiente propício à expressão do reconhecimento, deixando estas trabalhadoras expostas a agravos à sua saúde.

\section{A clínica do trabalho: espaço de discussão e possibi- lidades de emancipação do sujeito através da escuta coletiva}

Conforme exposto, constata-se que a demanda na enfermagem é grande e diversificada, o que exige também capacidade de adaptação e senso de urgência e vigilância constantes. Aliado a isso, há a multiplicidade de corpos, cada um com a sua própria demanda, sendo altamente complexo lidar com essas variáveis, pois não se trata apenas de aplicar técnicas, mas sim de acompanhar o cuidado prestado ao paciente e sua evolução, que não é apenas física, mas também emocional e afetiva. Ao encontro disso, está o posicionamento de uma participante da pesquisa: "a gente nunca sabe o que vai acontecer. Certeza a gente nunca tem, então tem que estar sempre vigilante, alerta” (Beth).

Verifica-se, dessa forma, que o trabalhador da enfermagem precisa usar sua capacidade de empatia e sua sensibilidade. No entanto, ao mesmo tempo, manter o distanciamento necessário para que o espelhamento, ou seja, a identificação e o envolvimento com o paciente, conforme apontado por Beck (2001), não impeça o seu raciocínio sobre as estratégias adequadas a cada situação.

Este conflito gera um paradoxo advindo de um circuito afetivo difícil de ser vivenciado. Acrescenta-se a isto a constatação diária das limitações da técnica, que se 
confundem com as suas próprias, principalmente quando há experiências envolvendo mortes que, no entender das profissionais, conforme verbalizado por Suelen, com o apoio do grupo, não deveriam ocorrer: "Será que tinha que ser assim? Às vezes, a gente não sabe o que fazer, mas sente que podia ter sido diferente”.

Entretanto, conforme relatam as participantes da pesquisa, não há tempo para parar e avaliar o que aconteceu ou questionar. Além disso, expressam que, no seu entendimento, devem encarar a morte como normal em seu trabalho, sem expressar emoção ou pesar, embora seja evidente que a palavra emoção é constante nos discursos e que não é possível estar imunizado eficazmente, como desejariam, contra o sofrimento do outro e os seus pedidos de socorro. Em relação a isso, Pitta (1994) aponta que é próprio da atualidade esconder-se da morte, da dor e do sofrimento, bem como a concepção de que tudo deve voltar a ser produtivo o mais rápido possível.

Segundo Dejours (2001), este sistema que exige produtividade a qualquer custo produz e agrava as desigualdades e consegue fazer com que estas injustiças pareçam boas e justas. A novidade na contemporaneidade estaria, então, na banalização das adversidades, alimentando a trama da ordem econômica e social. Entretanto, Dejours (2004b) defende que, através da criação de espaços de discussão, mobiliza-se a coragem de se arriscar e cria-se um ambiente propício ao confronto com o real, tornando-se visíveis aspectos do trabalho, até então ignorados, e construindo formas coletivas de resolução.

A aplicação da Clínica do Trabalho no contexto da pesquisa evidenciou esta potência do espaço de discussão, pois possibilitou uma reflexão sobre o sofrimento, o prazer e as contradições da profissão, levando a um enfrentamento da realidade e permitindo sua ressignificação. A partir da escuta coletiva, as participantes começaram a refletir sobre sua prática e sobre suas demandas, descobrindo outras possibilidades de trabalho e caminhando de uma posição de submissão para uma mais saudável no exercício de suas funções, abrindo espaço para a criação e para a transformação.

Sobre a elevada demanda, as enfermeiras deram-se conta de que grande parte das exigências decorre do próprio profissional e, ao refletirem sobre a sobrecarga de tarefas, relataram que essa situação poderia ser diferente se elas próprias respeitassem mais os seus limites. Assim, pode-se considerar que, mesmo diante de todas as exigências impostas a este profissional, no contexto da lógica capitalista, há um espaço de transformação mediado pela palavra e pela ação coletiva. Porém, é muito difícil colocar isso em prática, conforme aborda Brenda em relação a essas exigências: "Só que não sei se nós não somos culpadas. A gente talvez permit[a] que isso aconteça”. Ainda acrescenta: "A gente está tão acostumada que acaba fazendo tudo. Às vezes é falta de confiança em deixar para o outro fazer [...]; é que se tu não faz, parece que é má vontade”. Constata-se, a partir desse relato, que a transformação desta organização não pode basear- -se em iniciativas isoladas que levem apenas a autoculpabilização e ao sentimento de impotência, mas, sim, precisa estar alicerçada na reflexão e na ação do coletivo de enfermeiras em busca de estratégias mais saudáveis e de soluções criativas que rompam com o modelo vigente.

Acredita-se assim que, apesar dos limites impostos pela lógica do capitalismo flexível que atravessa o cotidiano do enfermeiro no hospital, há brechas para um exercício profissional que corte laços perversos de submissão, acomodação e banalização das injustiças, pois, segundo Dejours (2004b), a relação do trabalhador com a organização é dinâmica e, portanto, passível de transformação e superação. Ou seja, a partir da reflexão, os sujeitos tornam-se capazes de se reapropriar da realidade de seu trabalho, o que possibilita "a mobilização necessária para impulsionar mudanças que tornem o trabalho menos penoso e mais saudável" (LANCMAN; SZNELWAR, 2004, p. 33).

Faz-se importante salientar, ainda, que a Psicodinâmica do Trabalho se opõe a visões deterministas que colocam os trabalhadores no lugar de meros observadores passivos e impotentes de um mundo perverso, reduzindo-os a sujeitos passivos e sem opção. Assim, considera que, a partir da criação de um espaço público, de discussão, tal como o proposto na presente pesquisa, pode-se impulsionar uma maior democracia das relações de trabalho e vislumbrar, mesmo diante do atual cenário econômico, organizações mais propícias à saúde e à realização: "Os trabalhadores são capazes de se proteger, de encontrar uma saída, possuem uma capacidade de emancipação, de reapropriação, de transformação e reconstrução da realidade" (LANCMAN; SZNELWAR, 2004, p. 34).

Em concordância, Dejours (2004d) afirma que as novas formas de gestão, de organização do trabalho e de organização geram tragédias e doenças, levando até mesmo à morte. Entretanto, existem organizações que podem ser favoráveis à saúde mental, ou seja, é possível, pela mediação da palavra, construir compromissos a serem conquistados entre trabalho e saúde. Desta forma, assim como o trabalho pode gerar o pior tanto em termos de saúde individual, como na perspectiva política, pode também proporcionar o melhor, constituindo um importante mediador da emancipação e não apenas da alienação. Contudo, para isso, é preciso que sejam abertos, nas organizações, espaços para "viver junto", para a reconstrução da solidariedade e do coletivo de trabalho, para pensar e discutir a ação.

A pesquisa confirmou estes pressupostos, tendo em vista ter sido possível constatar que, ao longo das discussões, as participantes foram fazendo novas descobertas, tornando visíveis aspectos até então ocultos e mudando sua postura diante do real e dos constrangimentos de seu trabalho.

Uma importante constatação do grupo, construída na escuta coletiva, ocorreu quando a pesquisadora propôs a reflexão sobre o reconhecimento de si mesmo. Este momento foi marcante para o grupo, que percebeu 
a importância do apoio, da deliberação coletiva e da comunicação autêntica entre os pares. Desde então, houve momentos significativos de reconhecimento mútuo, citando eventos e fatos sobre contribuições de suas colegas que, embora estivessem registrados na memória, nunca haviam sido verbalizados.

Este movimento do grupo rumo às relações de trabalho mais saudáveis denota a importância dos espaços de discussão, através dos quais se abre uma senda para o reconhecimento de um fazer que constitui importante elo de ligação entre os pares e que confere sentido ao trabalho, bem como um suporte na elaboração e no enfrentamento, possibilitando a ressignificação de frustrações e perdas inerentes à profissão.

Segundo Dejours (2004d), toda a organização é desestabilizadora da saúde. Ou seja, não há organização de trabalho sem sofrimento. Entretanto, há organizações mais favoráveis à negociação desse sofrimento.

Analisando a organização na qual esta pesquisa foi realizada, pode-se inferir que parece não favorecer a superação do sofrimento, tendo em vista a rigidez das regras e das prescrições, o nível de exigência e a intensidade do trabalho. O espaço público proporcionado pela pesquisa possibilitou que o grupo deixasse circular, através da palavra, seu sofrimento em relação aos limites impostos pela rotina, o que permitiu uma postura crítica diante disso e a liberação do desejo de mudar o que é possível. As profissionais perceberam o quanto esta ação é desafiante para quem, geralmente, submete-se a rotinas e regras preestabelecidas. Pode-se identificar essa perspectiva através da fala de Lisa: "Ser radical com as regras é mais cômodo, mudar exige apoio, tu te envolver, é mais difícil".

Este relato mostra a acomodação como uma defesa difícil de ser desmobilizada em direção à realização do desejo de flexibilizar as regras e exercer sua criatividade, engenhosidade e inteligência prática. Contudo, a esse respeito, Dejours (2004b) coloca que, ao deslocar os limites do real, correndo riscos em relação aos regulamentos prescritos pela organização de trabalho, pela mobilização da inteligência, o trabalhador pode conquistar o prazer e a saúde através de seu trabalho.

Apoiadas umas pelas outras no processo de intercompreensão propiciado pela discussão, as participantes decidiram que poderiam correr alguns riscos, quebrar as barreiras da organização prescrita e flexibilizar as regras em favor do paciente. Em concordância, Brenda afirma: "Acho que todos podem ter flexibilidade. Cada caso é um caso". Além disso, para ilustrar aquilo que defende, Brenda cita uma das regras, afirmando que a prescrição pode ser tangenciada:

Diz que o banho tem que ser de manhã, só que [...] isso nem sempre é bom [...] às vezes o paciente passou a noite em claro e precisou tomar remédio pra conseguir dormir às 4 horas da manhã. Como é que vai tomar banho?

A análise destas constatações ratifica a posição de Dejours (2004b) de que a organização é dinâmica e seu movimento e sua evolução podem ser impulsionados pela escuta coletiva.

A interpretação dos comentários do grupo revelou, assim, que, através do espaço de discussão, pode ser deflagrado um movimento de transformação, potencializado pela circulação da palavra, possibilitando a retomada da posição de sujeito em busca de soluções criativas diante das contradições da organização de trabalho. Este movimento pode possibilitar uma ação rumo à desrotinização, à flexibilização das regras e ao trabalho real, pois, conforme relato de uma das enfermeiras "a rotina desumaniza” (Zilá).

A reflexão com o grupo possibilitou, ainda, um olhar atento à saúde destas cuidadoras. As participantes constataram, ao longo das discussões, que as especificidades dessa profissão são desfavoráveis à sua saúde, assim como afirma Beth: "A gente nunca se atrasa, não se permite nem ficar doente, de atestado". Vivian complementa a fala da colega declarando que:

A responsabilidade em avaliar o paciente pra repassar ao médico é muito grande. Precisa ligar pro médico, não precisa? Os demais da equipe não dominam isso. A gente vai levando, não para pra pensar, mas é muito difícil a nossa profissão.

As participantes relatam também que não cuidam de sua saúde, dando visibilidade a mais uma estratégia de defesa que é a negação do próprio corpo, de suas dores e seus limites. Apontam que descuidam de sua saúde e deixam seu corpo chegar ao limite para então reconhecer que precisam de ajuda e de cuidados. Paola afirma que: "É como se fosse dada uma ordem pro corpo: 'tu não pode sentir, vai aguentando' [...]. Eu precisei ficar muito doente pra entender que como tu vai cuidar de uma pessoa se tu não tá bem?”. A mesma participante ainda acrescenta: "A gente não fala e ninguém sabe, só percebe quando já estourou, porque acham que a gente é forte e dá conta”.

Outra enfermeira questiona-se, após os relatos das colegas: "Será que eu também vou chegar no limite? Acho que comigo não vai acontecer [...] ou será que vai? Agora estou ouvindo e me assustando" (Lisa). E na riqueza da interlocução, uma participante responde ao questionamento da colega: "É! A gente acha que não vai chegar pra gente esse dia de explodir tudo e ser difícil se recuperar. Tu vai esperar chegar?" (Sandra). Por fim, o grupo constata: "Vai chegando um ponto em que a corda arrebenta, não dá pra continuar negando isso" (Susi). E ainda: "A enfermeira é uma pessoa igual a outra, fica doente, fica cansada” (Zilá).

A tentativa de anestesiar seu corpo pode constituir outra importante estratégia de defesa que possibilita lidar com a dor e a morte do paciente e com os rigores da profissão, entretanto, pode trazer danos graves à saúde desta trabalhadora. Considera-se importante relatar que as interpretações da pesquisadora, perguntando se tem que ser assim, produziram efeitos no grupo: "Não. A gente não tem que ser forte o tempo todo [...] É a emoção que dá sentido" (Nina). 
As participantes constataram também, através das discussões, que existem ações que podem mudar a realidade e que não são, necessariamente, vítimas das situações vivenciadas. Ou seja, perceberam que podem enfrentá-las e transformá-las, como se pode constatar a partir da fala de Renata: "Realmente não tem que ser assim, a gente talvez permita que isso aconteça [...]. Acaba fazendo tudo; aceitando tudo, não coloca limite” (Renata). A participante acrescenta com apoio verbal das colegas: "A gente vai levando mesmo, mas parando pra pensar não precisa ser assim tão sofrido". Faz-se interessante salientar que as participantes abordam o "parar para pensar", ou seja, demonstram compreender a importância da reflexão coletiva propiciada com o espaço de discussão e as descobertas dele provenientes.

Dejours (1999, p. 176) descreve esta possibilidade de retomada da posição de sujeito, autor de sua história no trabalho, a partir da escuta coletiva, onde pode ocorrer na intersubjetividade o "milagre da palavra". Através dele, são revelados fatos ou raciocínios que o sujeito "sabia sem saber" e que são extremamente importantes como geradores de saúde e realização.

Pode-se considerar, dessa forma, que espaços abertos de discussão e circulação da palavra (DEJOURS, 2004b), tal como o que foi possibilitado no decorrer da pesquisa, podem liberar o potencial criativo destas profissionais, mobilizando estratégias concretas de mudança e enfrentamento propícias ao reconhecimento da contribuição efetiva deste trabalhador junto ao paciente e à organização, conforme relato: "Precisamos ser escutados, ser cuidados [...] se cuidar para poder cuidar" (Zilá). Esta fala anuncia uma importante demanda de escuta e o desejo de transformar o sofrimento vivenciado, fundando novas possibilidades de vida e saúde no exercício da enfermagem.

Fica evidente, assim, a necessidade de continuar esse processo que foi apenas iniciado através da pesquisa, ampliando os espaços de comunicação na organização hospitalar, o qual oportuniza aos cuidadores um ambiente singular de convivência, manifestação de seu desejo, expressão de suas ideias, exercício de sua inteligência e criatividade. Enfim, ele oportuniza reconhecimento de seu fazer, tornando visível sua contribuição à organização e reconstruindo o sentido deste trabalho.

\section{Considerações finais}

A análise crítica do trabalho imaterial no contexto dos trabalhadores da enfermagem tornou visíveis as formas de dominação da sociedade de acumulação flexível que perpassa este contexto com profundas repercussões sobre as relações de trabalho, deflagrando novos assujeitamentos e novas formas de controle, com seus impactos diretamente sobre a saúde destes trabalhadores.

No que se refere à natureza do trabalho imaterial neste campo de atuação, foi possível perceber que a enfermagem apresenta demandas próprias da contempo- raneidade, intensificadas pelo capitalismo em sua forma atual, principalmente no que se refere às relações afetivas permeadas por exigências de tempo integral e polivalência, o que leva a demandas opostas, ou seja, dedicar-se aos vínculos, mas, concomitantemente, agir com rapidez para manter-se produtivo e apto para gerar lucro em um contexto de acirrada competitividade.

Assim, há uma exigência de aproximação, interação, humanização e, contraditoriamente, um imperativo de distanciamento associado ao ter que dar conta de tudo e não demonstrar seus sentimentos ou falar sobre eles, demandando ainda entrega de "corpo e alma” deste trabalhador ao seu ofício, não para ser reconhecido e caminhar em busca de sua realização e emancipação, mas para manter o círculo de produção e consumo no qual criar, conviver e dialogar são considerados supérfluos e, portanto, perda de tempo.

Outro aspecto importante a ser salientado é quanto à exigência de ter que dar conta do trabalho, de ter que ser forte e de que é proibido adoecer ou se emocionar. Isso constitui fonte de sofrimento para estas trabalhadoras e impede a elaboração das vivências dolorosas da profissão, bem como o encontro com o sentido deste trabalho.

Aliadas a isso, existem outras fontes de sofrimento, sendo que serão retomadas as principais fontes identificadas: os ritmos e os horários de trabalho; as duplas ou triplas jornadas também relacionadas às questões de gênero; a convivência cotidiana com a dor e a morte, associada ao sentimento de culpa relatado quando um paciente morre, pois sentem que algo mais poderia ter sido feito ou de que erraram em alguma coisa; as urgências e emergências, gerando a pressão do tempo; a imprevisibilidade de cada turno, exigindo constante vigilância e adaptação às variações do estado dos pacientes; os diferentes corpos e doenças e seus diferentes pedidos de socorro; o sentimento de despreparo para gerenciar seus subordinados; e, ainda, o sentimento de desvalor. A estas fontes, acrescentam-se imperativos contemporâneos que atravessam a profissão e que intensificam as vivências de sofrimento e dificultam sua transposição. Dentre estes, podemos citar o individualismo e a restrição dos espaços de convivência; o pouco espaço para o reconhecimento do trabalho do enfermeiro associado à tendência crescente de afastamento do cuidado direto do paciente e de sua família; a redução dos postos de trabalho exigindo polivalência, rodízio de funções e elevado ritmo de trabalho. Pode-se citar, ainda, a insegurança aliada à instabilidade crescente no cenário econômico; o aumento das demandas para um número reduzido de trabalhadores; o pouco espaço e tempo para construção de relações de trabalho alicerçadas na cooperação e na solidariedade; a proliferação de doenças; o avanço tecnológico exigindo novas competências e habilidades; e a desumanização dos sistemas de gestão baseados em metas e controles rigorosos.

Este cenário aponta para a doença profissional, pois, uma vez não enfrentados, estes fatores tornam-se insuportáveis, podendo levar à morbidade, conforme 
relatado pelas participantes ao falarem acerca de sua saúde e do desrespeito aos seus limites. Estes problemas físicos e psíquicos são mantidos em silêncio ou invisíveis mesmo para o profissional, que não ouve os apelos de seu próprio corpo, considerando que a ordem institucional, alimentada pelos próprios profissionais, é de manter-se dentro de uma suposta normalidade e produtividade.

Salienta-se que, certamente, há um potencial imenso de realização para os enfermeiros, entretanto, considera-se fundamental falar do sofrimento e da dor para que este seja ressignificado, desnaturalizado e não mais reprimido. Além disso, considera-se muito importante a construção de uma identidade profissional fundamentada na valorização do papel de cuidador, rumo ao reconhecimento de um conjunto de teorias e técnicas, ou seja, de um saber constituído cientificamente em relação ao cuidar, como parte essencial, e não acessória ao tratamento.

Pode-se considerar, assim, que as estratégias subversivas construídas no espaço que se abre para além do discurso hegemônico dos poderes instituídos na organização hospitalar e na superação das regras da organização prescrita possibilitam o acesso ao reconhecimento de uma prática que, no decorrer de sua história, foi construída à sombra.

Acredita-se que, através do rompimento de preconceitos e da desvinculação do paradigma dominante, pode ser possível ao enfermeiro alcançar visibilidade, legitimando seu saber, centralizado no cuidar e no cuidado, e buscando o reconhecimento científico de sua importância e complexidade como ação complementar e não auxiliar ao tratamento. Assim, rompe com a resignação diante do sofrimento e o transforma em sofrimento criativo e saudável ou, ainda, em fonte impulsionadora de novas relações de trabalho. Não se pretende com isso desconsiderar a importância do amor à profissão, que pode ser altamente saudável, desde que não leve à submissão e à alienação que culminam com o adoecimento.

Outrossim, a discussão de ideias e o compartilhamento de vivências, tanto frustrantes, quanto vitoriosas, pode levar ao encontro de saídas e soluções rumo ao alcance dos objetivos da organização hospitalar e da emancipação profissional, tornando visível a contribuição deste trabalhador através da expressão de sua criatividade e inteligência associada à experiência prática, que atuam como impulsionadores do reconhecimento - essencial à preservação da saúde e/ou à superação da doença.

Vale retomar, aqui, a afirmação de Dejours (2004b, p. 58) no que tange ao homem e à organização de trabalho:

A relação entre a organização de trabalho e o homem não é um bloco rígido, está em contínuo movimento [...] a estabilidade aparente desta relação está assentada em um equilíbrio livre e aberto à evolução e às transformações, um equilíbrio dinâmico, em contínuo deslocamento.
É preciso, assim, despertar as organizações para a importância desta relação. Nesta direção, a comunicação e a cooperação não somente técnica, conforme propõe Dejours (2004b), podem propiciar a compreensão da possibilidade de um exercício profissional que permita criar, a partir do sofrimento compartilhado, uma nova atmosfera no ambiente de trabalho. Esta será capaz de ressignificar a existência profissional para a busca de novas atitudes e relações de trabalho.

Por fim, acreditamos que uma das principais contribuições desta pesquisa foi demonstrar, através de seus resultados, a importância dos espaços de discussão como mobilizadores e potencializadores de saúde nas organizações. Isto é, estes espaços podem possibilitar ao profissional o encontro com o sentido de seu trabalho através da elaboração de seus sentimentos e emoções, do fortalecimento do sentimento de equipe e dos laços de solidariedade necessários à quebra da aridez do individualismo, considerando que, para Dejours (2004d), ao contrário do que é propagado pelo capitalismo contemporâneo, o individualismo constitui uma derrota e não um ideal.

Este trabalhador necessita falar, ouvir e ser ouvido, assumindo, enfrentando e desnaturalizando seu sofrimento e buscando um sentido para ele, bem como mobilizando novas estratégias de defesa - que no contexto estudado, embora apareçam no coletivo, são criadas e vividas individualmente - que promovam formas mais saudáveis de adaptação e/ou de superação. Considera-se que a escuta do grupo através da metodologia da Psicodinâmica do Trabalho, embora tenha ocorrido em um período relativamente curto, cumpriu com os propósitos de uma pesquisa-ação, intervindo neste contexto e promovendo formas mais saudáveis de trabalho. Este espaço deveria ser mantido e ampliado nas organizações hospitalares, dada sua importância no bem-estar deste trabalhador, conforme fica evidenciado no relato que segue: "Eu ainda não me cuido, mas depois de ouvir as colegas algo mudou dentro de mim e eu vou mudar minha vida, não vou deixar chegar no limite [...]" (Lisa).

Conforme Merlo e Mendes (2009), a mobilização do fazer em busca de transformação deflagra uma mobilização que é também sociopolítica. Os autores concluem, assim, que essa metodologia "revela-se um instrumento para intervenção, prevenção e transformação de processos de trabalho agressivos à saúde psíquica” (MERLO; MENDES, 2009, p. 152). Sendo assim, considera-se que se deve buscar ampliar continuamente estes espaços de circulação da palavra, acreditando ser possível romper com a desumanização das relações de trabalho, apostando no ser humano que trabalha, pois: "o trabalho é, por definição, humano, uma vez que é mobilizado ali onde a ordem tecnológica e maquinal é insuficiente" (DEJOURS, 2004b, p. 62). Tal afirmação torna-se extremamente significativa no contexto de trabalho imaterial estudado, no qual o ser humano é o centro da atividade. 


\section{Contribuições de autoria}

Os dois autores tiveram contribuição substâncial no projeto e no delineamento da pesquisa, no levantamento de dados e na análise e interpretação dos resultados, bem com na elaboração crítica do manuscrito e na aprovação da versão a ser publicada.

\section{Referências}

BECK, C. L. C. O sofrimento do trabalhador: da banalização à re-significação ética na organização da enfermagem. 2001. 199 f. Tese (Doutorado em Enfermagem)-Faculdade de Enfermagem, Universidade de Florianópolis, Santa Catarina, 2001.

DEJOURS, C. A loucura do trabalho: estudo de psicopatologia do trabalho. São Paulo: Oboré/Cortez, 1992.

Conferências brasileiras: identidade, reconhecimento e transgressão no trabalho. São Paulo: Fundap; EAESP/FGV, 1999

. A banalização da injustiça social. 4. ed. Rio de Janeiro: FGV, 2001.

. Subjetividade, trabalho e ação. Revista Produção, São Paulo, v. 14, n. 3, p. 27-34, dez. 2004a.

Da psicopatologia à psicodinâmica do trabalho. In: LANCMAN, S.; SZNELWAR, L. I. (Org.). Christophe Dejours: da psicopatologia à psicodinâmica do trabalho. Rio de Janeiro: Fiocruz; Brasília: Paralelo 15, 2004b. Addendum, p. 47-104.

. A metodologia em psicodinâmica do trabalho. In: LANCMAN, S.; SZNELWAR, L. I. (Org.). Christophe Dejours: da psicopatologia à psicodinâmica do trabalho. Rio de Janeiro: Fiocruz; Brasília: Paralelo 15, 2004c. Cap. 2, p. 105-126.

. Avant-propos para a edição brasileira. In: LANCMAN, S.; SZNELWAR, L. I. (Org.). Christophe Dejours: da psicopatologia à psicodinâmica do trabalho. Rio de Janeiro: Fiocruz; Brasília: Paralelo 15, 2004d. p. 15-21.

. O trabalho como enigma. In: LANCMAN, S.; SZNELWAR, L. I. (Org.). Christophe Dejours: da psicopatologia à psicodinâmica do trabalho. Rio de Janeiro: Fiocruz; Brasília: Paralelo 15, 2004e. Cap. 3. p. 127-147.

DEJOURS, C.; BÈGUE, F. Suicídio e trabalho: o que fazer? Brasília: Paralelo 15, 2010.

GERNET, I. Psicodinâmica do reconhecimento. In: MENDES, A. M. et al. (Org.). Psicodinâmica e clínica do trabalho: temas, interfaces e casos brasileiros. Curitiba: Juruá, 2010. p. 61-76.

GONZÁLES, R. M. B. Sofrimento na práxis da enfermagem: real ou deslocado em seu sentido? 2001. 195 f. Tese (Doutorado em Enfermagem)-Faculdade de Enfermagem, Universidade de Florianópolis, Santa Catarina, 2001.

HARDT, M.; NEGRI, A. Império. 2. ed. Rio de Janeiro: Record, 2001.

LANCMAN, S.; HELOANI, R. Psicodinâmica do trabalho: o método clínico de intervenção e investigação. Revista Produção, São Paulo, v. 14, n. 3, p. 77-86, set./dez. 2004.

LANCMAN, S.; SZNELWAR, L. I. (Org.) Apresentação. In: _. Christophe Dejours: da psicopatologia à psicodinâmica do trabalho. Rio de Janeiro: Fiocruz; Brasília: Paralelo 15, 2004. p. 33-34.

LAZZARATTO, M.; NEGRI, A. Trabalho imaterial: formas de vida e produção de subjetividade. Rio de Janeiro: DP \& A, 2001.

LEOPARDI, M. T. et al. O processo de trabalho em saúde: organização e subjetividade. Florianópolis: Papa Livros, 1999.

MARTINS, S. R. Intervenções em grupo na clínica do trabalho: uma experiência anunciada em sonho. In: MENDES, A. M. et al. (Org.). Psicodinâmica e clínica do trabalho: temas, interfaces e casos brasileiros. Curitiba: Juruá, 2010. p. 347-363.

MENDES, A. M.; MORRONE, C. F. Trajetória teórica e pesquisas brasileiras sobre prazer e sofrimento no trabalho. In: MENDES, A. M. et al. (Org.) Psicodinâmica e clínica do trabalho: temas, interfaces e casos brasileiros. Curitiba: Juruá, 2010. p. 29-52.

MERLO, A. R. C.; LAPIS, N. L. A saúde e os processos de trabalho no capitalismo: algumas considerações. Boletim da Saúde. Escola de Saúde Pública/RS, Porto Alegre, v. 19, n. 1, p. 17-29, 2005.

MERLO, A. R. C.; MENDES, A. M. B. Perspectivas do uso da psicodinâmica do trabalho no Brasil: teoria, pesquisa e ação. Cadernos de Psicologia Social e do Trabalho, São Paulo, v. 12, n. 2, p. 141-156, 2009.

MOLINIER, P. Sujeito e subjetividade: questões metodológicas em psicodinâmica do trabalho. Revista Terapia Ocupacional, São Paulo, v. 14, n. 1, p. 43-47, jan./abr. 2003.

A dimensão do cuidar no trabalho hospitalar: abordagem psicodinâmica do trabalho de enfermagem e dos serviços de manutenção. Revista Brasileira de Saúde Ocupacional, v. 33, n. 118, p. 6-16, 2008. 
NARDI, H. C. A propriedade social como suporte da existência: a crise do individualismo moderno e os modos de subjetivação contemporâneos. Psicologia e Sociedade, Santa Catarina, v. 15, n. 1, p. 37-56, jan./ jun. 2003.

PÉRILLEUX, T. Clínica do trabalho e crítica social. In: MENDES, A. M. et al. (Org.). Psicodinâmica e clínica do trabalho: temas, interfaces e casos brasileiros. Curitiba: Juruá, 2010. p. 145-163.

PITTA, A. Hospital: dor e morte como ofício. São Paulo: Hucitec, 1994.

SANT'ANNA, D. Corpos de passagem: ensaios sobre a subjetividade contemporânea. São Paulo: Estação Liberdade, 2001.

SENNETT, R. A corrosão do caráter: consequências pessoais do trabalho do novo capitalismo. Rio de Janeiro: Record, 2004.
SILVA, A. L. A. enfermagem na era da globalização: desafios para o século XXI. Revista Latino-Americana de Enfermagem, Ribeirão Preto, v. 16, n. 4, p. 787-790, 2008.

SZNELWAR, L. I. Introdução. In: LANCMAN, S.; SZNELWAR, L. I. (Org.). Christophe Dejours: da psicopatologia à psicodinâmica do trabalho. 2. ed. Rio de Janeiro: Fiocruz; Brasília: Paralelo 15, 2008.

TRAESEL E. S.; MERLO, A. C. A psicodinâmica do reconhecimento no trabalho de enfermagem. Revista PSICO. Rio Grande do Sul, v. 40, n. 1, p. 102-109, jan./ mar. 2009.

Sofrimento no trabalho e possibilidades de saúde e realização: psicodinâmica do reconhecimento em enfermagem. In: MENDES, A. M. et al. (Org.).

Psicodinâmica e Clínica do Trabalho: temas, interfaces e casos brasileiros. Curitiba: Juruá, 2010. p. 291-311. 